A report to the Missouri Department of Conservation

\title{
Threats of Habitat and Water-Quality Degradation to Mussel Diversity in the Meramec River Basin, Missouri, USA
}

Open-File Report 2011-1125 



\section{Threats of Habitat and Water-Quality Degradation to Mussel Diversity in the Meramec River Basin, Missouri, USA}

By Jo Ellen Hinck, Christopher G. Ingersoll, Ning Wang, Tom Augspurger, M. Christopher Barnhart, Stephen E. McMurray, Andrew D. Roberts, and Lynn Schrader

A report to the Missouri Department of Conservation

Open-File Report 2011-1125 


\section{U.S. Department of the Interior \\ KEN SALAZAR, Secretary \\ U.S. Geological Survey \\ Marcia K. McNutt, Director}

\section{U.S. Geological Survey, Reston, Virginia: 2011}

For more information on the USGS - the Federal source for science about the Earth, its natural and living resources, natural hazards, and the environment, visit http://www.usgs.gov or call 1-888-ASK-USGS.

For an overview of USGS information products, including maps, imagery, and publications, visit http://www.usgs.gov/pubprod

To order this and other USGS information products, visit http://store.usgs.gov

Any use of trade, product, or firm names is for descriptive purposes only and does not imply endorsement by the U.S. Government.

Although this report is in the public domain, permission must be secured from the individual copyright owners to reproduce any copyrighted materials contained within this report.

Suggested citation:

Hinck, J.E., Ingersoll, C.G., Wang, N., Augspurger, T., Barnhart, M.C., McMurray, S.E., Roberts, A.D., and Schrader, L, 2011, Threats of habitat and water-quality degradation to mussel diversity in the Meramec River Basin, Missouri, USA. US Geological Survey Open File Report 2011-1125, 18 p. 


\section{Acknowledgments}

Funding for this project was provided by Area Strategic Integrated Science and Technology Funds of the U.S. Geological Survey. The findings and conclusions in this article do not necessarily represent the views of the U.S. Fish and Wildlife Service. J. Scott Faiman provided additional information on native mussels in Missouri, and Aaron Garringer and Kimberly Chojnacki produced the map. W. Gregory Cope, James Fairchild, and Christopher Schmitt reviewed earlier drafts of this paper.

\section{Contents}

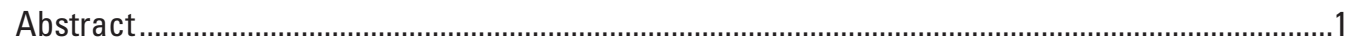

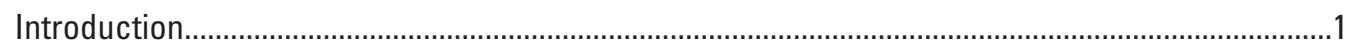

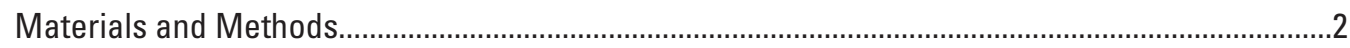

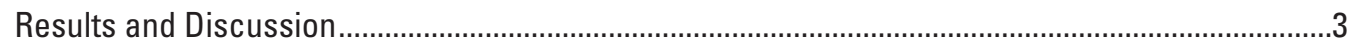

Physical Habitat Attributes of Mussel Populations ....................................................................3

Mussel Distributions in the Meramec River Basin .............................................................4

Identifying Threats to Mussel Populations in the Meramec River Basin..................................4

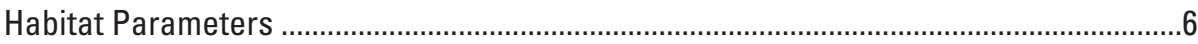

Excess Sedimentation.........................................................................................

Altered Stream Geomorphology and Flow ...........................................................

Altered Riparian Vegetation and Condition ............................................................7

Impoundments......................................................................................................

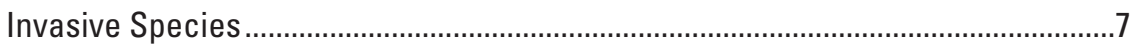

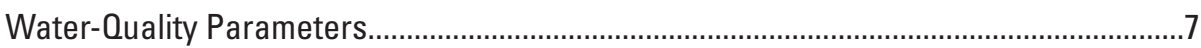

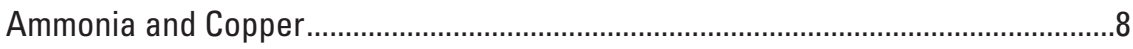

Chlorine

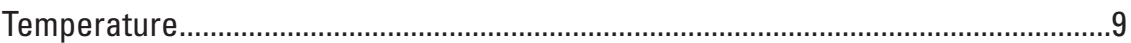

Future Research and Management Needs for Mussel Populations.....................................9

Continue to Implement the Best Management Practices to Restore Riparian

Habitat ........................................................................................................

Conduct Further Analyses of Historical Mussel Distribution, Land Use, and Water-

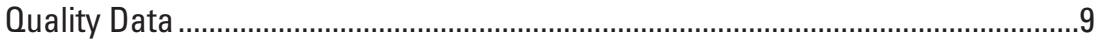

Monitor Zebra Mussels in the Meramec River Basin .................................................12

Conduct Landscape Scale Modeling to Predict Mussel Distributions............................12

Protect Water Quality in Greater Biodiversity Areas as a Matter of Public Policy........12

Implement Monitoring Studies to Assess Effects of Wastewater Treatment Plants and Areas of Suspected Nonpoint Source Pollution on Mussel Beds ...............12

Determine Sublethal Effects of Chemical Contaminants of Concern (for example, Ammonia, Metals, Common Use Pesticides, Synthetic Hormones, Medications, Personal Care Products) to Mussels .....................................................................13

Derive Risk-Based Guidance Values for Mussel Protection............................................13

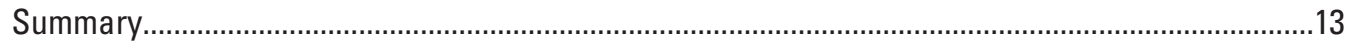

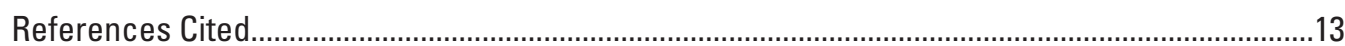




\section{Figure}

1. Map of the Meramec River Basin, Missouri, USA

\section{Tables}

1. Unionid mussels found in the Meramec River Basin based on historical survey data from 1977-78 (Buchanan, 1980) and 1997 (Roberts and Bruenderman, 2000). Taxonomy based on Turgeon and others (1988), except where accepted changes have occurred. Only resurveyed sites from the Meramec River $(n=28)$, Bourbeuse River $(n=17)$, and Big River $(n=5)$ are included. Number of sites $(n=50)$ based on living and dead individuals

2. Toxicity data for freshwater mussels based on water-only exposures. Number of species included in the range of effect concentrations is in parenthesis for each life stage

\section{Conversion Factors}

SI to Inch/Pound

\begin{tabular}{lcl}
\hline & Multiply & \multicolumn{1}{c}{ To obtain } \\
\hline liter (L) & Volume & \\
liter (L) & 33.82 & ounce, fluid (fl. oz) \\
liter (L) & 2.113 & pint (pt) \\
liter (L) & 1.057 & quart (qt) \\
liter (L) & 0.2642 & gallon (gal) \\
& 61.02 & cubic inch (in $\left.{ }^{3}\right)$ \\
\hline gram (g) & Mass & \\
milligram (mg) & 0.03527 & ounce, avoirdupois (oz) \\
\hline & 0.00035 & ounce, avoirdupois (oz) \\
\hline kilometer $(\mathrm{km})$ & Length & miles (mi) \\
\hline
\end{tabular}

Temperature in degrees Celsius $\left({ }^{\circ} \mathrm{C}\right)$ may be converted to degrees Fahrenheit $\left({ }^{\circ} \mathrm{F}\right)$ as follows: ${ }^{\circ} \mathrm{F}=\left(1.8 x^{\circ} \mathrm{C}\right)+32$

Concentrations of chemical constituents in water are given either in milligrams per liter (mg/L) or micrograms per liter $(\mu \mathrm{g} / \mathrm{L})$.

Salinities are given in parts per thousand equivalent to grams per liter (g/L). 


\title{
Threats of Habitat and Water-Quality Degradation to Mussel Diversity in the Meramec River Basin, Missouri, USA
}

\author{
By Jo Ellen Hinck, Christopher G. Ingersoll, Ning Wang, Tom Augspurger, M. Christopher Barnhart, \\ Stephen E. McMurray, Andrew D. Roberts, and Lynn Schrader
}

\section{Abstract}

The Meramec River Basin in east-central Missouri is an important stronghold for native freshwater mussels (Order: Unionoida) in the United States. Whereas the basin supports more than 40 mussel species, previous studies indicate that the abundance and distribution of most species are declining. Therefore, resource managers have identified the need to prioritize threats to native mussel populations in the basin and to design a mussel monitoring program. The objective of this study was to identify threats of habitat and waterquality degradation to mussel diversity in the basin. Affected habitat parameters considered as the main threats to mussel conservation included excess sedimentation, altered stream geomorphology and flow, effects on riparian vegetation and condition, impoundments, and invasive non-native species. Evaluating water-quality parameters for conserving mussels was a main focus of this study. Mussel toxicity data for chemical contaminants were compared to national water quality criteria (NWQC) and Missouri water quality standards (MWQS). However, NWQC and MWQS have not been developed for many chemical contaminants and some MWQS may not be protective of native mussel populations. Toxicity data indicated that mussels are sensitive to ammonia, copper, temperature, certain pesticides, pharmaceuticals, and personal care products; these compounds were identified as the priority water-quality parameters for mussel conservation in the basin. Measures to conserve mussel diversity in the basin include expanding the species and life stages of mussels and the list of chemical contaminants that have been assessed, establishing a long term mussel monitoring program that measures physical and chemical parameters of high priority, conducting landscape scale modeling to predict mussel distributions, determining sublethal effects of primary contaminants of concern, deriving risk-based guidance values for mussel conservation, and assessing the effects of wastewater treatment plants and non-point source pollution on mussels. A critical next step to further prioritize these needs is to conduct a watershed risk assessment using local data (for example, land use, flow) when available.

\section{Introduction}

Native unionoid mussels (Mollusca: Bivalvia: Unionoida) are important components of aquatic ecosystems, and global declines in mussels have emphasized the need for their protection and conservation. Of the approximately 300 mussel species in North America, nearly 70 percent are of special concern, threatened, endangered, or extinct (Williams and others, 1993). Missouri has 69 species of native mussels (Missouri Department of Conservation [MDC], 2008). The Meramec River Basin in east-central Missouri contains one of the most diverse unionoid faunas in the central United States with more than 40 species reported (Buchanan, 1980; Roberts and Bruenderman, 2000), several of which have special conservation status. Pink mucket (Lampsilis abrutpa) and scaleshell (Leptodea leptodon) are Federal and State endangered species, and ebonyshell (Fusconaia ebena), elephantear (Elliptio crassidens), and snuffbox (Epioblasma triquerta) are State endangered species. In addition, 9 other species in the basin are of conservation concern in Missouri (Roberts and Bruenderman, 2000). Mussel populations in the basin appear more stable in terms of diversity and abundance than other regions in the United States (Abell and others, 2000), but declines of endangered and threatened species have been reported (Roberts and Bruenderman, 2000). Therefore, resource managers are developing a mussel conservation strategy that addresses the main threats to native populations.

The Meramec River Basin drains 5,566 square kilometers before entering the Mississippi River downstream form St. Louis, Missouri (fig. 1; Buchanan, 1980). Base flows are sustained by springs indicative of the area's karst topography and two primay tributaries, the Big and Bourbeuse Rivers. Courtois, Crooked, Dry, Dry Fork, Huzzah, and Indian Creeks and the Little Meramec River are smaller, but important tributaries to the Meramec River. The upper basin is primarily forest and agriculture with a relatively small human population (about 50,000 ), whereas the lower basin is heavily populated (greater than 500,000) and urbanized. Overall, water quality is considered good compared to other basins in the State, but point and non-point source pollution from hundreds of dischargers 


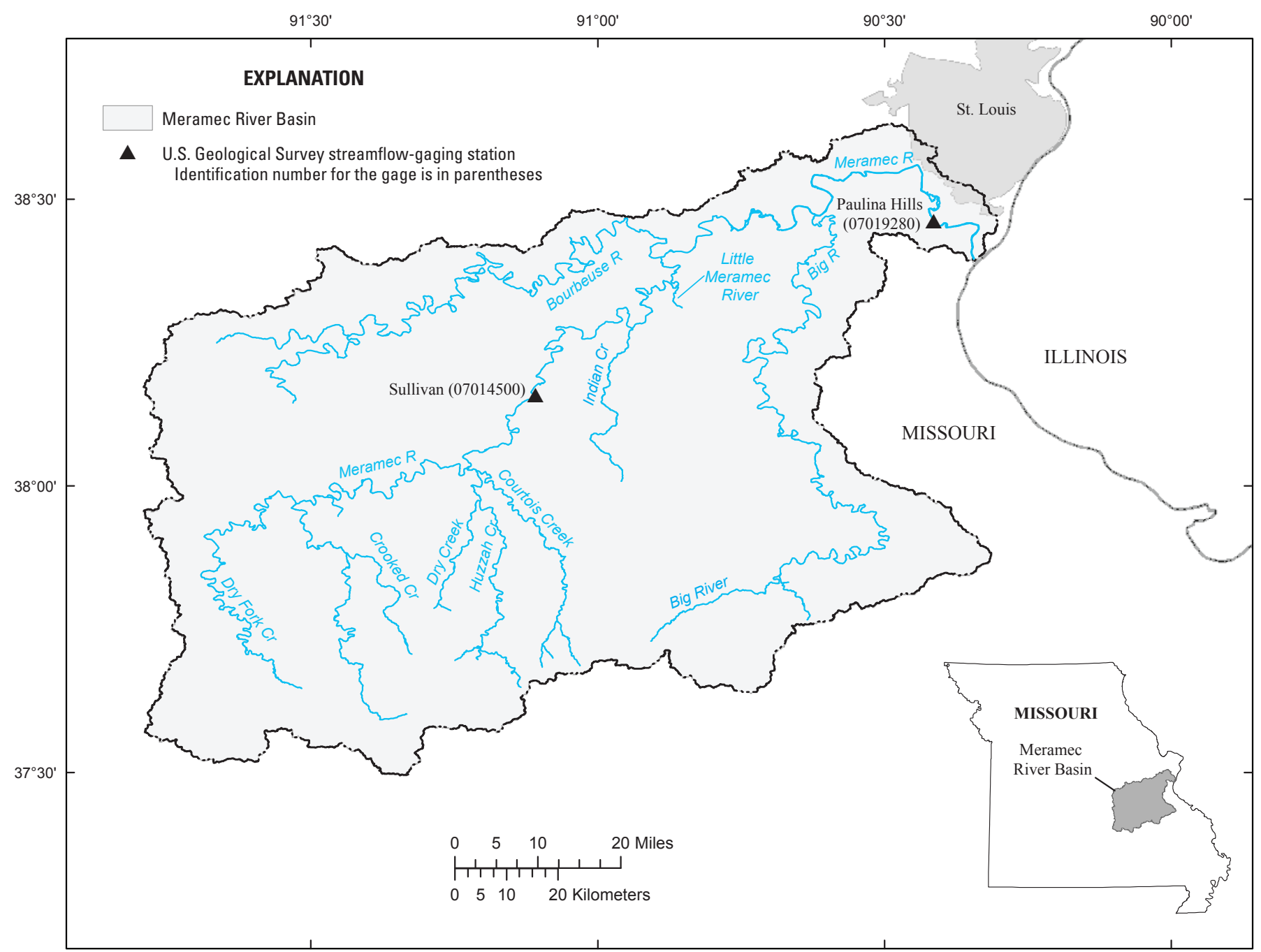

Figure 1. Meramec River Basin, Missouri, USA

occurs within the basin (Annis and others, 2009). Livestock grazing, logging, and mining (lead, sand, and gravel) are primary activities within the basin (Blanc and others, 1998), which have the potential to affect mussel populations. Cattle access to streams in the basin can lead to increased stream channel disturbance (runoff, erosion, and sediment production), excessive nutrient loading, and injury to riparian areas (for example, Brim Box and Mossa, 1999). In-stream gravel mining can increase sediment transport in rivers and streams (Brown and others, 1998; Hubbs and others, 2006) and tailing ponds from lead mining operations may release heavy metals, sediments, and nutrients into streams. In addition, sediments, contaminated runoff, and hydromodification threaten water quality in urbanized areas of the lower basin.

The objective of this study was to identify and evaluate the threats of habitat and water-quality degradation to mussel diversity to be considered in mussel monitoring efforts within the Meramec River Basin. A review of the physical habitat attributes important to maintaining healthy native mussel populations was the first objective. Secondly, mussel distributions and declines of species in the basin were described, and then lists of habitat and water-quality threats in the basin that have the potential to affect mussel distributions and density were developed. Mussel-specific toxicity data were compiled, summarized, and compared to national water quality criteria (NWQC) and Missouri water quality standards (MWQS) to screen potential water-quality threats to mussel populations. The final objective was to develop research and management needs for conserving mussel diversity in the basin. These objectives are complementary to the goals of the Missouri Mussel Conservation and Management Plan (Missouri Department of Conservation, 2008) and could be adapted to other basins where mussel conservation is a priority.

\section{Materials and Methods}

Historical data from mussel surveys conducted in 1977-78 and 1997 (Buchanan, 1980; Roberts and Bruenderman, 2000) were reviewed and tabulated. The 1997 survey resampled many of the 1977-78 study sites on the main stem of 
the Meramec River to determine the current status of mussels in the basin and used similar methodology to allow for comparisons with the 1977-78 survey (Roberts and Bruenderman, 2000). The 1997 survey specifically documented the status of rare and endangered taxa.

Water-only chemical toxicity data for mussels, regardless of species, were compiled from the scientific literature and reviewed. Data preference was for acute (short-term) exposures of 24 hour (h) for glochidia and $96 \mathrm{~h}$ for juveniles (American Society for Testing and Materials, 2010), but acute toxicity data from shorter exposure durations were included if these were not available. Acute effects endpoints were generally median lethal effect concentrations (LC50s) and median effect concentrations (EC50s) based on immobilization because these are the most commonly reported values for short-term exposures. Although not an objective of the current study, effect concentrations would need to be lowered to estimate a no- or low-effect threshold for a chemical contaminant. For example, the U.S. Environmental Protection Agency (1985) uses a multiplier of 0.5 to approximate a low level of effect from EC50 data. More conservative no- or low-effect acute concentrations can be estimated by applying a factor of 0.43 as derived by Dwyer and others (2005). Suitable chronic data (for example, no observed effect concentrations, no observed adverse effect levels, chronic values) were included when available. These data were then summarized by chemical parameter and life stage and compared to the current NWQC (U.S. Environmental Protection Agency, 1999, 2006, 2007, 2009) and the MWQS (Missouri Department of Natural Resources, 2008) to screen potential water-quality threats to mussels. The toxicity of several metals including cadmium, copper, lead, nickel, and zinc is affected by water-quality characteristics such as water hardness or dissolved organic carbon, and the toxicity of ammonia is dependent on $\mathrm{pH}$ and temperature. Therefore, normalization of these water-quality parameters for these contaminants is needed to compare effect concentrations directly to NWQC and MWQS.

\section{Results and Discussion}

\section{Physical Habitat Attributes of Mussel Populations}

Mussels in the Meramec River Basin occur in dense, patchy aggregations, referred to as mussel beds, in which a variety of species may be found. Mussel beds require appropriate food sources, host fishes, temperature, depth, flow, minimal sedimentation by fine-grained particulates, and minimal pollutants in the water or sediments (Strayer, 2008). However, habitat requirements of mussels are not well understood (Gore and others, 2001) and life history characteristics of specific species are lacking (Resh and Rosenberg, 2010). In the
Meramec River Basin, mussel beds genrally were more successful in areas of stable substrate and constant flow. Flooding can rearrange stream-bed habitat and scour riparian corridors, which can cause mussel mortality by desiccation, damage by moving coarse substrate, crushing from deposit of large substrata, and downstream relocation (Hastie and others, 2001); host fish mortality and dislocation also may be important factors. Mussel populations also may be affected by climate change. Reduced flows, increased temperature, and habitat alteration may result in prolonged periods of drought for mussel beds, increased sedimentation, algal growth, and organic debris, and declines in host fish (Hastie and others, 2003).

Microhabitat measurements such as current speed, water depth, distance to shore, and sediment size are of limited use for predicting mussel abundance and distribution (Strayer and Ralley, 1993; Layzer and Madison, 1995; Gore and others, 2001; Gangloff and Feminella, 2007). Flow requirements for mussels differ among species and with time (Layzer and Madison, 1995; Gore and others, 2001). For example, the patchiness of mussel communities may be the result of mussels utilizing flow refugia, or stable riverbed areas with low hydraulic stresses during floods (Strayer, 1999). Strayer and Ralley (1993) concluded that measuring physical parameters, such as current speed, water depth, distance from shore, presence of macrophytes, and sediment size, were of limited use in predicting the density and distribution of mussels in lotic systems at the microhabitat scale, but such parameters modeled at the landscape scale may have greater predictive power. More complex models that incorporated hydraulic characteristics and geomorphology also have been suggested (Layzer and Madison, 1995; Gangloff and Feminella, 2007; Newton and others, 2008; Strayer, 2008). For example, Gangloff and Feminella (2007) reported that shear stress during high flow events affected mussel distributions; stream geomorphology affected mussel abundance; and stream size affected species richness.

Many species of mussels are considered indicators of high quality aquatic habitats because of their sensitivity to environmental perturbations (Grabarkiewicz and Davis, 2008). As a group, mussels generally are sensitive to changes in their habitat or watershed that alter flow, substrate stability, and sedimentation. Prolonged time to reproductive maturity, host specificity for transformation of juveniles, low juvenile survival rate to maturity, and limited dispersal make mussels potentially susceptible to habitat disturbances. Unlike many aquatic organisms, mussels are long lived and sedentary, with little ability to move away from threats in the local environment. The multiple life-stages of unionoid mussels (glochidia, juveniles, and adults) are a unique life history characteristic, which results in various exposure pathways including surface water, sediment, pore water, diet, and host fish tissue (Cope and others, 2008). For example, juvenile and adult mussels are suspension- and deposit- feeders, which expose them to chemical pollutants in sediments and water (Vaughn and others, 2008). 
Threats of Habitat and Water-Quality Degradation to Mussel Diversity in the Meramec River Basin, Missouri, USA

\section{Mussel Distributions in the Meramec River Basin}

Mussel surveys in the basin were conducted in 1977-78 (Buchanan, 1980) and in 1997 (Roberts and Bruenderman, 2000). The 1977-78 survey was prompted by proposed dam construction in basin. Buchanan (1987) concluded that high quality streams within the basin were able to maintain their diverse and abundant mussel populations even after large dieoffs; however, this may not be true for greatly altered streams (for example, channelization, increased urban or agricultural runoff). Typical habitat for mussels in the basin was speciesspecific, with five distribution categories described including headwater species, upper and middle river species, middle and lower river species, lower river species, and cosmopolitan (Buchanan, 1980). Flow, water depth, and substrate requirements differed among species (Buchanan, 1980).

Overall, mussel distribution and diversity in the basin declined from 1977 to 1997 . Of the 42 species collected, all were found at fewer sites in 1997 compared to those in 1977-78 (table 1). The number of individual mussels collected also was generally lower in 1997 (table 1). Elephantear and ebonyshell (both State endangered species) and pondmussel were collected in 1977-78 but were not found in 1997 (table 1). In addition, the distribution of slippershell (Alasmidonta viridis; State species of conservation concern), salamander mussel (Simpsonaias ambigua; State species of conservation concern), yellow sandshell (Lampsilis teres), lilliput (Toxolasma parvus), and fawnsfoot (Truncilla donaciformis) decreased to one location in the basin (table 1). Distributions, based on the number of sites present, of federally endangered pink mucket and scaleshell declined between 1977-78 and 1997 surveys (table 1). Declines in the distributions between 1977-78 and 1997 for other species of concern including elktoe (Alasmidonta marginata), giant floater (Pyganodon grandis), sheepnose (Plethobasus cyphyus), snuffbox, black sandshell (Ligumia recta), northern brokenray (Lampsilis reeviana brittsi), rock pocketbook (Arcidens confragosus), and spectaclecase (Cumberlandia monodonta) also occurred (table 1). Mussel density and diversity was greatest in the lower basin (Buchanan, 1980, Roberts and Bruenderman, 2000), and few sites resampled in the upper basin supported mussels (Roberts and Bruenderman, 2000). Although several small tributaries in the upper basin are considered Outstanding State Resource Waters (Blanc and others, 1998), mussel populations generally have not been diverse in the Dry Fork Creek of the Meramec River, Huzzah Creek, or Courtois Creek. The low diversity of mussel beds in smaller tributaries may be attributed to steeper gradients, greater velocities, lack of soft substrates, absence of appropriate fish hosts, or a combination of these factors (Morris and Corkum, 1999).

Of the 42 mussel species found in the basin during the 1977-78 survey (Buchanan, 1980), the ellipse (Venustaconcha ellipsiformis), flutedshell (Lasmigona costata), giant floater, northern brokenray, plain pocketbook (Lampsilis cardium), slippershell, and Wabash pigtoe (Fusconaia flava) were the most common species in the upper basin. There were fortyone mussel species identified in the basin in 1997 (Roberts and Bruenderman, 2000), with an average of 9 species and 184 living mussels per site. Many of the mussel beds sampled by Buchanan (1980) were still viable in 1997, but most new beds were found in the lower basin. Of the few mussels found in the upper basin, mucket (Actinonaias ligamentina), pimpleback (Quadrula pustulosa), plain pocketbook, purple wartyback (Cyclonaias tuberculata), threeridge (Amblema plicata), and Wabash pigtoe were the most common species in 1997 (Roberts and Bruenderman, 2000). Overall, mucket, threeridge, spike (Elliptio dilatata), Wabash pigtoe, plain pocketbook, round pigtoe (Pleurobema sintoxia), pink heelsplitter (Potamilus alatus), pimpleback, and ellipse had the broadest distributions in the basin in 1977-78 and 1997 (table 1). In 1997, the most common mussels in the basin (in order of relative species abundance) were spectaclecase, mucket, threeridge, washboard (Megalonaias nervosa), pimpleback and round pigtoe. Few young (for example, greater than 10 years old) mucket, spectaclecase, or threeridge were found, and there was little evidence of recruitment for washboard, round pigtoe, or pimpleback in the basin (Roberts and Bruenderman, 2000); however, slow growth rates may confound these data. In addition, recruitment of various mussel species has been reported in the lower basin but not the upper basin (Roberts and Bruenderman, 2000).

Several factors may affect mussel distribution and abundance in the basin. Appropriate host fish species may not be available in all reaches or have a short residency time. Host fish parasitized by glochidia may have temporary immunity for other mussel species; therefore, mussels may have to compete for host fish (Rogers and Dimock, 2003). Host fish also can have an acute, nonselective tissue response that leads to premature glochidia detachment or host fish can acquire immunity after multiple infections (Roberts and Barnhart, 1999). In addition, host infection strategies (for example, lure type) could affect mussel distribution and abundance (Barnhart and others, 2008). Further elucidating the life history strategies of mussels in the basin (for example, timing and method of glochidia release, timing of glochidia transformation on host fish) may aid in understanding some species declines in the basin.

\section{Identifying Threats to Mussel Populations in the Meramec River Basin}

Threats were divided into habitat parameters and water-quality measurements. These groups were addressed separately, as lack of suitable physical habitat supersedes water-quality issues that may exist. Within each of these discussions, a list of top parameters to maintain mussel diversity and distribution is presented based on current scientific information from published studies. These lists are intended to be protective of mussel populations in general and are not specific to the basin. The primary data referenced should be 
Table 1. Unionid mussels found in the Meramec River Basin based on historical survey data from 1977-78 (Buchanan, 1980) and 1997 (Roberts and Bruenderman, 2000).

[n, number of sites. Taxonomy based on Turgeon and others (1988), except where accepted changes have occurred. Only resurveyed sites from the Meramec River $(n=28)$, Bourbeuse River $(n=17)$, and Big River $(n=5)$ are included. Number of sites $(n=50)$ based on living and dead individuals.]

\begin{tabular}{|c|c|c|c|c|c|c|}
\hline \multirow[b]{2}{*}{ Species } & \multirow[b]{2}{*}{ Common name } & \multicolumn{3}{|c|}{ Number of sites } & \multicolumn{2}{|c|}{ Number of living individuals } \\
\hline & & 1977-78 & 1997 & $\begin{array}{c}\text { Distribution } \\
\text { change } \\
\text { (percent) }\end{array}$ & 1977-78 & 1997 \\
\hline Actinonaias ligamentina & Mucket & 46 & 39 & -14 & 3,261 & 1,417 \\
\hline Alasmidonta marginata ${ }^{1}$ & Elktoe & 33 & 7 & -52 & 63 & 11 \\
\hline Alasmidonta viridis ${ }^{1}$ & Slippershell & 5 & 1 & -8 & 35 & 0 \\
\hline Amblema plicata & Threeridge & 43 & 34 & -18 & 3,120 & 1,088 \\
\hline Arcidens confragosus ${ }^{1}$ & Rock pocketbook & 8 & 2 & -12 & 8 & 9 \\
\hline Cumberlandia monodonta ${ }^{1,2}$ & Spectaclecase & 21 & 18 & -6 & 446 & 189 \\
\hline Cyclonaias tuberculata & Purple wartyback & 23 & 16 & -14 & 71 & 77 \\
\hline Ellipsaria lineolata & Butterfly & 23 & 15 & -16 & 99 & 75 \\
\hline Elliptio crassidens ${ }^{3}$ & Elephantear & 4 & 0 & -8 & Shell only & 0 \\
\hline Elliptio dilatata & Spike & 46 & 33 & -26 & 886 & 213 \\
\hline Epioblasma triquerta $^{3}$ & Snuffbox & 17 & 3 & -28 & 14 & 17 \\
\hline Fusconaia ebena ${ }^{3}$ & Ebonyshell & 3 & 0 & -6 & 3 & 0 \\
\hline Fusconaia flava & Wabash pigtoe & 49 & 35 & -28 & 448 & 159 \\
\hline Lampsilis abrupta $^{3,4}$ & Pink mucket & 9 & 4 & -10 & 15 & 7 \\
\hline Lampsilis cardium & Plain pocketbook & 49 & 36 & -26 & 586 & 103 \\
\hline Lampsilis reeviana brittsi ${ }^{1}$ & Northern brokenray & 14 & 3 & -22 & 76 & 26 \\
\hline Lampsilis siliquoidea & Fatmucket & 17 & 11 & -12 & 1,115 & 98 \\
\hline Lampsilis teres & Yellow sandshell & 37 & 8 & -58 & 120 & 13 \\
\hline Lasmigona complinata & White heelsplitter & 17 & 6 & -22 & 26 & 2 \\
\hline Lasmigona costata & Fluted shell & 40 & 10 & -60 & 77 & 31 \\
\hline Leptodea fragilis & Fragile papershell & 36 & 14 & -44 & 70 & 50 \\
\hline Leptodea leptodon ${ }^{3,4}$ & Scaleshell & 9 & 6 & -6 & 11 & 30 \\
\hline Ligumia recta $^{1}$ & Black sandshell & 33 & 20 & -26 & 144 & 22 \\
\hline Ligumia subrostrata & Pondmussel & 3 & 0 & -6 & 5 & 0 \\
\hline Megalonaias nervosa & Washboard & 16 & 13 & -6 & 583 & 331 \\
\hline Obliquaria reflexa & Threehorn wartyback & 22 & 11 & -22 & 34 & 71 \\
\hline Plethobasus cyphyus 1,2 & Sheepnose & 29 & 11 & -36 & 44 & 30 \\
\hline Pleurobema sintoxia & Round pigtoe & 45 & 31 & -28 & 395 & 354 \\
\hline Potamilus alatus & Pink heelsplitter & 43 & 27 & -32 & 414 & 248 \\
\hline Potamilus ohiensis & Pink papershell & 4 & 2 & -4 & 17 & 3 \\
\hline Pyganodon grandis & Giant floater & 31 & 10 & -42 & 249 & 28 \\
\hline Quadrula metanevra & Monkeyface & 22 & 12 & -20 & 30 & 56 \\
\hline Quadrula pustulosa & Pimpleback & 42 & 33 & -18 & 707 & 395 \\
\hline Quadrula quadrula & Mapleleaf & 6 & 3 & -6 & 67 & 82 \\
\hline Quadrula merrucosa & Pistolgrip & 42 & 21 & -42 & 63 & 33 \\
\hline Simpsonaias ambigua ${ }^{1}$ & Salamander mussel & 1 & 1 & 0 & 5 & 5 \\
\hline Strophitus undulates & Creeper & 40 & 8 & -64 & 140 & 20 \\
\hline Toxolasma parvus & Lilliput & 9 & 1 & -16 & 24 & 10 \\
\hline Truncilla donaciformis & Fawnsfoot & 9 & 1 & -16 & 10 & 2 \\
\hline Truncilla truncata & Deertoe & 27 & 11 & -32 & 52 & 55 \\
\hline Utterbackia imbecillis & Paper pondshell & 20 & 3 & -34 & 83 & 20 \\
\hline Venustaconcha ellipsiformis & Ellipse & 43 & 27 & -32 & 384 & 209 \\
\hline
\end{tabular}

${ }^{1}$ State- species of conservation concern.

${ }^{2}$ Federally listed - endangered (candidate).

${ }^{3}$ State listed-endangered.

${ }^{4}$ Federally listed-endangered. 
examined if specific species are of concern. In addition, these parameters also can affect host fish distribution and density, which can lead to indirect effects on mussels. Furthermore, the absence of host fish would preclude mussel persistence even if adequate habitat and water quality were available. Site specific data for the habitat and water-quality parameters described herein are lacking in the Meramec River Basin; therefore, the parameters identified could be used to direct future mussel monitoring in the basin.

Determining habitat parameter and water-quality thresholds that are protective of mussel populations is complex, and a single numerical criterion for any given parameter may not be appropriate for all mussel species or their unique life-stages (Cope and others, 2008). Descriptions of various habitat parameters important to mussel conservation have been reviewed previously and are discussed briefly (for example, Brim Box and Mossa, 1999; Richter and others, 2000; Lydeard and others, 2004; Strayer, 2008). Prioritization of waterquality parameters, especially for chemical contaminants, is lacking and is considered in more detail. Specifically, few protective chemical contaminant thresholds have been developed for mussels because of limited research and the general lack of NWQC and MWQS for a variety of contaminants (for example, pesticides, industrial chemicals, personal care products) and mixtures of contaminants. Furthermore, the contaminant exposure pathways (that is, water, sediment, diet), exposure durations, and relative sensitivities of the various mussel life stages are not well defined (Cope and others, 2008).

\section{Habitat Parameters}

Streams and rivers are dynamic systems, which limits the ability to determine a specific numerical range for physical habitat characteristics that will support a diverse mussel assemblage. Previous reviews have identified various habitat parameters that could be considered for mussel conservation (Brim Box and Mossa, 1999; Richter and others, 2000; Lydeard and others, 2004; Strayer, 2008). Habitat parameters important to mussel diversity and distribution are described below.

\section{Excess Sedimentation}

Deposition of fine-grained sediments is considered one of the main limiting factors of mussel and fish host diversity and distribution (Henley and others, 2000; Beussink, 2007). Mussel distribution can be affected by bed material composition, dynamics of suspended bed material load, and substrate composition changes related to land use (Brim Box and Mossa, 1999). Increased sediment loads can be from various sources including bank erosion and degradation, overland erosion, and channel degradation. The primary source of sedimentation in the basin is the conversion of riparian areas (Roberts and Bruenderman, 2000). Excess sediments alter the chemical and physical composition of the water and can interfere with respiration and feeding of aquatic biota (Watters,
1999). Mussel species differ in their sensitivities to sediment regime changes (Brim Box and Mossa, 1999), but in general, increased sedimentation leads to suffocation, reduced feeding efficiency, and decreased growth and survival (Aldridge and others, 1987). Fine sediments (sand, silt, and clay) are the primary concern for mussel beds, although some mussel species including giant floater, flat floater, paper pondshell, and yellow sandshell prefer a substrate of sand and fine sediment (Henley and others, 2000). Sand typically is carried in the bed load and may cause physical smothering (that is, burial), whereas silt and clay remain suspended, which may interfere with respiration and feeding (Henley and others, 2000).

The most comprehensive assessment of sediment loading would be to conduct a sediment budget for the Meramec River Basin, but this may not be financially feasible. Alternatively, reconnaissance surveys could be conducted to document likely sources (for example, outside bends with exposed sediments, cattle crossings, in-stream gravel mining, undercutting of stream banks) in reaches where sedimentation is suspected to be problematic in the basin. Areas where stormwater runoff is documented also could be surveyed. Turbidity and discharge could be monitored in these areas to better understand temporal and spatial changes in sediment loads. Baseline versus post-storm monitoring would help determine the severity of sediment load increases after storm or flood events.

\section{Altered Stream Geomorphology and Flow}

Measurements of stream geomorphology include water depth, bottom and mid-depth current velocity, shear stress, channel width, bankfull depth, bankfull width, channel gradient, and bed substrate size. Mussel abundance and richness have been associated with current velocity, stream size, and shear stress (Gangloff and Feminella, 2007). Shear stress also has been suggested as a primary factor in determining habitat suitability for juvenile mussels (Layzer and Madison, 1995). Gangloff and Feminella (2007) reported that mussel abundance consistently was low at sites subject to high-shear stress and suggested that habitat conditions during flooding, and not summer base flow, limited mussel abundance. Changes in land use can alter stream geomorphology, which could affect mussel diversity and distribution (Gangloff and Feminella, 2007). Geomorphology characteristics are flow-conditional, and flow requirements for mussels vary temporally and by species (Layzer and Madison, 1995). In addition to flow, which is being measured at various locations in the basin (http://waterdata.usgs.gov/nwis), other stream geomorphology data could be monitored.

Characteristics of stable mussel beds in the Meramec River Basin include firm substrates with a thin layer of algae. Typical substrates include rocks of varying sizes intermixed with finer sediments (fine-grained sand, silt, and clay; Buchanan, 1980). Degraded mussel beds in the basin have unconsolidated substrates lacking algal coatings and do not contain finer-grained sediments. In-stream gravel mining, conversion of riparian vegetation, and increased runoff from 
impermeable surfaces may be affecting mussel bed stability in the lower basin. In-stream gravel mining activity increases substrate instability, bank erosion, sedimentation, and pollutant release (Brown and others, 1998; Hubbs and others, 2006). Recreational activities within the basin, such as the use of power boats and personal watercraft, cause turbulence and increase sediment resuspension that also can affect mussel beds (Aldrich and others, 1987).

\section{Altered Riparian Vegetation and Condition}

Distributions of mussel species can vary among riparian habitats (Morris and Corkum, 1999). Removal of the riparian corridor can disrupt mussels by increasing runoff, water temperatures, bed erosion, and channel degradation. Wetland habitats also are important to consider for their buffering capacity of high flows during rainfall events and filtering of contaminants. Riparian corridor information is available for the Meramec River Basin (Sowa and others, 2007) but would need to be updated as development and associated impervious surfaces are likely to increase with time and best management practices (for example, limiting cattle access to streams) continue to be applied in the basin. Restoring and protecting riparian areas may help conserve mussel populations in the Meramec River Basin.

\section{Impoundments}

Dams and the impoundments created by dams have caused well-documented effects on mussel populations. Creation of impoundments flood stream channels, alters flow and velocity, changes water depths, and alters sedimentation (Watters, 1996). Dams also can disrupt reproduction of mussels by limiting the movement of host fish, altering fish host assemblages and benthic diversity, decreasing genetic diversity through isolation, reducing low flows, and depleting oxygen levels. Dams with a height as low as 1 meter can restrict mussel distributions, most likely as a result of disrupted host fish movement and migration (Watters, 1996). There are hundreds of dams in the basin (Annis and others, 2009); mussel beds near these impoundments could be monitored to determine effects on mussel populations.

\section{Invasive Species}

Several non-native species pose a risk to mussel diversity and density in the Meramec River Basin. Zebra mussels (Dreissena polymorpha) have been confirmed in the lower Meramec River, where they likely were introduced when boats from the Mississippi River went upstream during high flows. Unlike unionoid mussels, zebra mussels do not require an intermediate host species for their reproduction so their proliferation can be rapid. Zebra mussels are very invasive once introduced to a system and can compete with many native mussel species for habitat (Ricciardi, 2003). Zebra mussels also can starve and suffocate native mussels by attaching to their shells (Mackie, 1991). However, zebra mussel density and distribution currently are not monitored in the basin.

Asian clams (Corbicula fluminea), which also are not native to the Meramec River Basin but have a widespread distribution (Roberts and Bruenderman, 2000), are a potential threat to native mussel populations. Neves (1987) suggested that Asian clams may compete with unionoid mussels for food and habitat, and introduce diseases and parasites to aquatic systems. Adult Asian clams can affect recruitment of glochidia and juvenile unionoid mussels through incidental siphoning (Yeager and others, 2000). In addition, ammonia production resulting from large die-offs of Asian clams also may be deleterious to native mussels (Bidwell and others, 2003).

\section{Water-Quality Parameters}

Common water-quality parameters measured in surface waters include bacteria, trace elements, chemical contaminants, major cations, major anions, dissolved oxygen, $\mathrm{pH}$, temperature, total dissolved gas, and turbidity. Water quality generally is considered good in streams, rivers, and lakes with diverse and abundant mussel populations (Grabarkiewicz and Davis, 2008). However, water quality can be degraded by point and non-point source pollution, which can affect aquatic organisms including mussels. Specifically, organic nutrients from agricultural practices and municipal effluents can degrade water quality by causing eutrophication, which can negatively affect mussels or fish hosts by decreasing water flow from increased plant biomass, depleting dissolved oxygen, altering $\mathrm{pH}$, and altering food sources (Fuller, 1974). In addition, common pollutants (such as ammonia, nitrates, phosphorus, chlorine, and oxygen consuming wastes) and chemical contaminants (such as metals, personal care products, and pharmaceuticals) can enter streams through wastewater treatment facilities. The possible long-term effects of these compounds on mussels and host fish or their quantities in the Meramec River Basin are unknown.

Studies to determine water-quality needs for mussel populations in the Meramec River Basin have not been conducted. Some water-quality parameters including temperature, $\mathrm{pH}$, alkalinity, hardness, dissolved oxygen, turbidity, conductivity, ammonia, nitrates, and sulfates were measured occasionally at mussel beds during the 1997 survey (Roberts and Bruenderman, 2000). In addition, two active gaging stations on the Meramec River (near Sullivan and Paulina Hills) collect water-quality data regularly (fig. 1; http://waterdata.usgs. gov/nwis). Quantitative chemical contaminant data specific to mussels in the basin are limited to heavy metal (lead and cadmium) concentrations in plain pocketbook mussels in the Big River (Czarnezki, 1987; Schmitt and others, 1987), despite the numerous lead mines in the basin (Annis and others, 2009). The mining of heavy metals has negatively affected biota in the Big River in the lower Meramec River Basin (known as the Old Lead Belt), where lead and cadmium deposited in streambed sediments have accumulated in biota downstream from the mining district. The failure of tailing pond dams, 
continual erosion of tailing piles, and exposure to contaminated sediments have eliminated much of the benthic community, including mussel populations, in the Big River (Schmitt and others, 1987; Roberts and others, 2009).

The NWQC and MWQS for the protection of aquatic life exist for less than 50 chemicals (http://www.epa.gov/waterscience/criteria/wqctable/index.html). Mussels can be more sensitive to certain contaminant classes than fish and other aquatic invertebrates commonly used to derive such criteria (Augspurger and others, 2007); therefore, established NWQC and MWQS for aquatic organisms may not be protective of mussels to all contaminants. In general, chemical contaminant sensitivity data are lacking for mussels. Few of the waters within the Meramec River Basin have been analyzed for chemical contaminants; therefore, potential exceedences of MWQS or risk-based estimates of protective values for mussels are unknown. Toxicity effects data were summarized and compared for chemical contaminants from the scientific literature to NWQC and MWQS to screen potential water-quality threats to mussels (table 2).

Mussel-specific toxicity data based on water-only exposures were available for only 17 of 39 parameters for which there are MWQS to protect aquatic life, and most data were limited to acute effects on early life stages of mussels (for example, glochidia or juveniles; table 2; Missouri Department of Natural Resources, 2008). Parameters for which there were MWQS (or NWQC) but no mussel-specific toxicity data include 2,4-dichlorophenol, 2-chloronaphthalene, aldrin, alkalinity, aluminum, arsenic, beryllium, chloride, chromium (III), cyanide, demeton, dieldrin, dissolved oxygen, endosulfan, endrin, ethylbenzene, guthion, heptachlor, heptachlor epoxide, hexachlorocyclopentadiene, hydrogen sulfide, iron, lindane, methoxychlor, mirex, oil and grease, $p, p$ '-DDT, parathion, phenol, selenium, silver, sulfide, total dissolved gases, and tributyltin; therefore, it is not known if these criteria are protective of mussels. Of the 17 parameters with mussel-specific toxicity data, effect concentrations for 4-nonylphenol, cadmium, chlorine, malathion, mercury, pentachlorophenol, and zinc are greater than the MWQS and NWQC for these chemicals, indicating that these aquatic criteria are protective of mussels (table 2). Mussel sensitivity data for chlordane, chlorpyrifos, chromium (VI), diazinon, lead, nickel, and toxaphene are limited to one species; therefore, too little information is available to determine if the MWQS and NWQC are protective of mussels. Mussel-specific effects data for ammonia and copper are less than MWQS and NWQC and may not be protective of mussels. These contaminants are discussed in more detail in the following sections. Acute toxicity data indicate that mussels are sensitive to certain glyphosate-containing pesticides, carbaryl, chlorothalonil, pyraclostrobin, and pharmaceuticals (for example, human prescription antidepressant drugs, fluoxetine) (Conners and Black, 2004; Gooding and others, 2006; Bringolf and others, 2007a, b; Cope and others, 2008), but NWQC and MWQS have not been developed for these chemical contaminants. If a particular chemical contaminant, which has no or limited toxicity data for mussels, is suspected in the
Meramec River Basin, consultation with experts on mussel sensitivity and toxicology would be useful to determine the risk to the mussel species present.

\section{Ammonia and Copper}

Early life-stages of various mussel species (glochidia and juveniles) are particularly sensitive to ammonia and copper (Wang and others, 2007a, b, 2008, 2009), and mussels adversely are affected at concentrations below MWQS and NWQC (table 2). As a result, the primary water-quality parameters to be measured for protecting mussel populations include ammonia and copper. Ammonia and copper are two of the most common pollutants in surface waters. Sources of ammonia include residential, agricultural and animal runoff, and wastewater treatment plants, and sources of copper include sediment loading from mining, agricultural applications, and natural weathering. Obtaining concentrations of ammonia and copper that protect mussels also may protect them from other water-quality issues; the best management practices and wastewater treatment necessary to manage these two pollutants could help manage other pollutants.

For ammonia, Wang and others (2007b) concluded that chronic NWQC (U.S. Environmental Protection Agency, 1999) may not protect mussels and determined a protective range would likely be 0.25 to 0.5 milligram of nitrogen per liter $(\mathrm{mg} / \mathrm{L})$ at $\mathrm{pH} 8$. Mussels are more sensitive to ammonia as $\mathrm{pH}$ increases (Wang and others, 2008); therefore, a $\mathrm{pH}$ adjustment is required for determining a threshold for the Meramec River Basin. This adjustment could be a sliding NWQC (U.S. Environmental Protection Agency, 1999) or a normalization to a $\mathrm{pH}$ at the high end of the normal range in the Meramec River Basin. To address mussel sensitivity to ammonia, the U.S. Environmental Protection Agency has drafted an update of the NWQC for ammonia that includes toxicity data for mussels (table 2; U.S. Environmental Protection Agency, 2009).

Copper is the most thoroughly studied chemical contaminant in terms of mussel toxicity (table 2). Acute toxicity data are available for numerous species, but effect concentrations vary by different test water characteristics (for example, hardness, dissolved organic carbon) and species. Given the acute and chronic effects data from the literature and accounting for hardness, the hardness-dependent MWQS may not be protective of mussel populations. However, deriving a protective value for copper is complex as the toxicity of copper is affected by various water characteristics, including hardness, alkalinity, $\mathrm{pH}$, and dissolved organic carbon (Erickson and others, 1996, U.S. Environmental Protection Agency, 2007, Wang and others, 2009). A biotic ligand model (BLM) has been developed to enable mechanistic modeling of copper bioavailability and acute toxicity as a function of these waterquality variables (Santore and others, 2001; U.S. Environmental Protection Agency, 2007). Whereas BLM-based NWQC for copper are more protective to mussels relative to previous hardness-dependent NWQC (March and others, 2007; Wang 
and others, 2009), the BLM has not been applied widely to state-derived standards. However, the BLM-based NWQC for copper only includes limited data for some mussel species (U.S. Environmental Protection Agency, 2007) and do not adequately protect all mussels (Wang and others, 2007a, 2007b, 2009). Chemical toxicity data along with other local water-quality data could be used to derive a protective copper concentration specific for mussels in the Meramec River Basin.

\section{Chlorine}

Primary sources of chlorine include wastewater treatment facilities and industrial plants, which could be monitored in the Meramec River Basin. Effect concentrations for early life-stage mussels are greater than NWQC and MWQS for chlorine (table 2). Therefore, waters achieving these NWQC and MWQS for chlorine could be protective of mussels, but some additional considerations are needed for discharge outfalls and mixing zones. Point source discharges may exceed their permitted NWQC, although little monitoring typically is conducted at outfalls. One discharge event, even if in short duration, that exceeds the criterion could kill mussels or entire mussel beds because mussels cannot move away from the point source discharge. Mixing zones can have regulated contaminant concentrations that exceed the NWQC for chlorine. Therefore, mussel beds in a mixing zone may have greater exposure to greater contaminant concentration because they are relatively sedentary. These considerations would not only apply to chlorine, but also apply to other chemical contaminants.

\section{Temperature}

Lethal temperatures are available for some mussel species, but NWQC and MWQS for temperature are limited (table 2). Nevertheless, temperature is an important parameter to consider as climate change concerns increase. Stream temperature can increase as a result of the lack of riparian cover, wastewater treatment plant outflows, and drought (Pandolfo and others, 2010). Temperature changes can affect mussels by altering food availability, host fish residency, and reproductive cues (Watters and O'Dee, 1998). For some mussels, greater temperatures $\left(21^{\circ} \mathrm{C}\right)$ reduced the transformation success of glochidia to juveniles on fish hosts, and juvenile mussels remain attached to the host fish for longer intervals at lower temperatures $\left(10^{\circ} \mathrm{C}\right.$; Roberts and Barnhart, 1999). This greater transformation success at low temperatures may be related to immunosupression of the host fish and would likely be species specific. Upper thermal tolerances also are species specific (Pandolfo and others, 2010). Pandolfo and others (2010) reported that median lethal temperatures ranged from 21 to $43^{\circ} \mathrm{C}$ in glochidia and 33 to $39^{\circ} \mathrm{C}$ in juveniles of eight mussel species.

\section{Future Research and Management Needs for Mussel Populations}

\section{Continue to Implement the Best Management Practices to Restore Riparian Habitat}

Restoring riparian and wetland habitats in the Meramec River Basin is likely to have positive effects on mussels by decreasing water temperature, sediment loads, and the physical destruction of habitat. Best management practice implementation also allows resource staff to educate private landowners on the importance of mussel populations in the Meramec River Basin and potentially conduct more reconnaissance on mussel bed status. For example, a private landowner may report a die-off in a stream reach not being monitored or historically assessed.

\section{Conduct Further Analyses of Historical Mussel Distribution, Land Use, and Water-Quality Data}

Timing is critical to identify the primary threats to mussels in the Meramec River Basin that contribute to losses in abundance and diversity (Missouri Department of Conservation, 2008). The most recent mussel survey in the Basin is already dated (Roberts and Bruenderman, 2000), and additional surveys have not been conducted because of logistical and budgetary constraints. Moreover, more extensive analyses of existing survey data have not been conducted. Species co-occurrence could be used to understand relations and habitat partitioning at specific sites. Evaluation of the 1977-78 survey in conjunction with the 1997 survey indicates possible causes for distribution changes and identifying mussel beds with diminished populations of certain species (table 1). For example, are the declines in the endangered sheepnose between 1979 and 1997 related to in-stream gravel mining, sedimentation, or turbidity? Incorporating other existing quantitative information such as water quality and fish assemblages would enhance these analyses. Changes in fish assemblages between surveys may help determine why species distributions have changed. Analysis of historical data also may highlight data gaps in mussel distributions which may require additional monitoring. Previous surveys were limited to bank-accessible sites; therefore, substantial mussel beds potentially occurring in boat-only accessible segments of the river have not been identified. Long-term monitoring protocols could be implemented at sites identified as high priority (MDC, 2008). Moreover, collecting and analyzing water-quality data would be informative to compare with toxicity effect thresholds of chemical contaminants. 
Table 2. Toxicity data for freshwater mussels based on water-only exposures.

[Number of species $(n)$ included in the range of effect concentrations is in parenthesis for each life stage. National water-quality criteria (NWQC) and Missouri water-quality standards (MWQS) are not mussel specific. Normalization of various water-quality parameters (for example, water hardness, $\mathrm{pH}$, dissolved organic carbon) is needed to directly compare effect concentrations of certain metals and ammonia to NWQC and MWQS (for example, March and others, 2007; Wang and others, 2010). mg/L, milligrams per liter; $\mathrm{NA}$, not available; >, greater than; $\mu \mathrm{g} / \mathrm{L}$, micrograms per liter; $\mathrm{CaCO}_{3}$, calcium carbonate; ${ }^{\circ} \mathrm{C}$, degrees $\mathrm{Celsius]}$

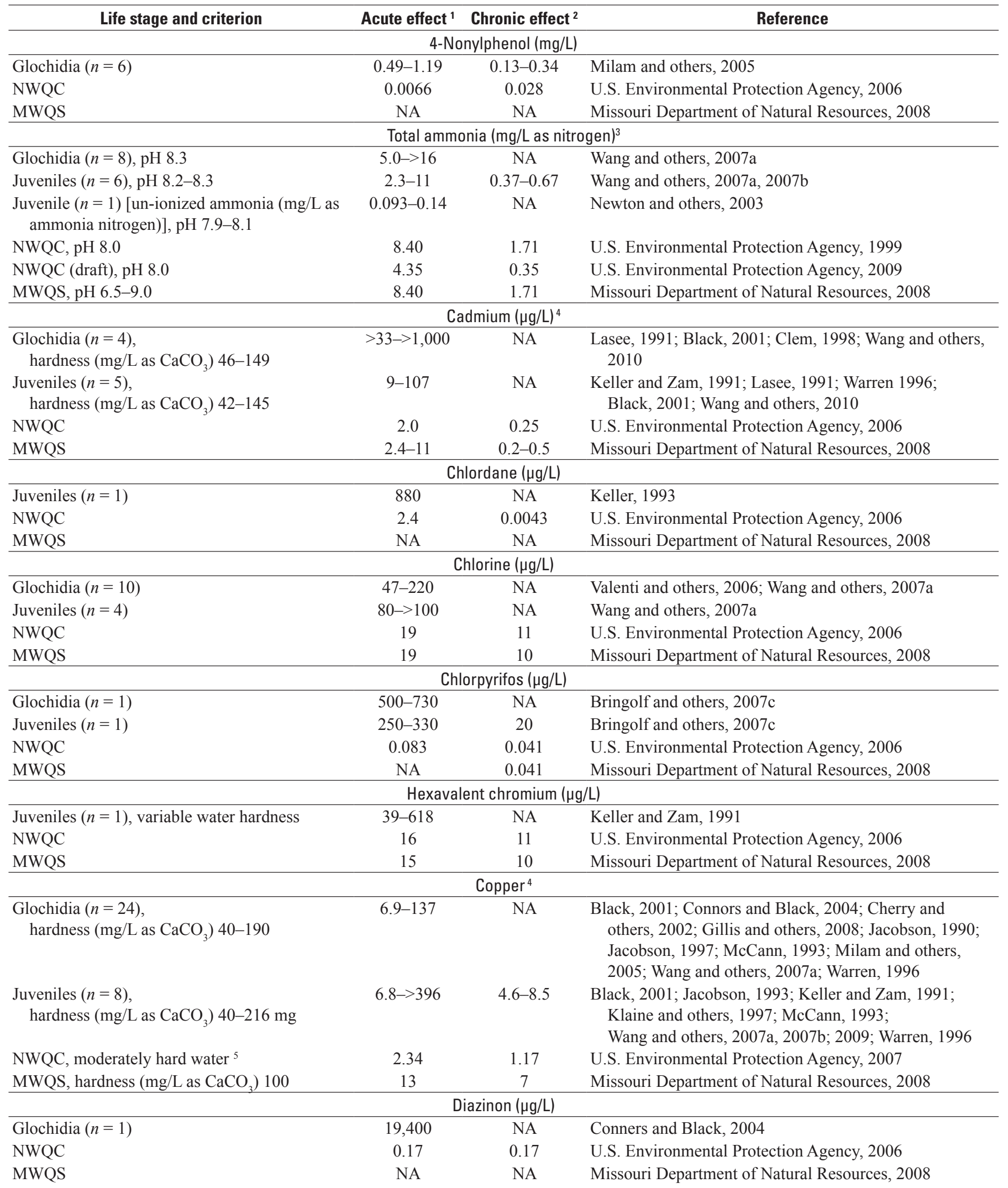


Table 2. Toxicity data for freshwater mussels based on water-only exposures.-Continued

[Number of species $(n)$ included in the range of effect concentrations is in parenthesis for each life stage. National water-quality criteria (NWQC) and Missouri water-quality standards (MWQS) are not mussel specific. Normalization of various water-quality parameters (for example, water hardness, $\mathrm{pH}$, dissolved organic carbon) is needed to directly compare effect concentrations of certain metals and ammonia to NWQC and MWQS (for example, March and others, 2007; Wang and others, 2010). mg/L, milligrams per liter; NA, not available; >, greater than; $\mu \mathrm{g} / \mathrm{L}$, micrograms per liter; CaCO ${ }_{3}$, calcium carbonate; ${ }^{\circ} \mathrm{C}$, degrees $\mathrm{Celsius}$

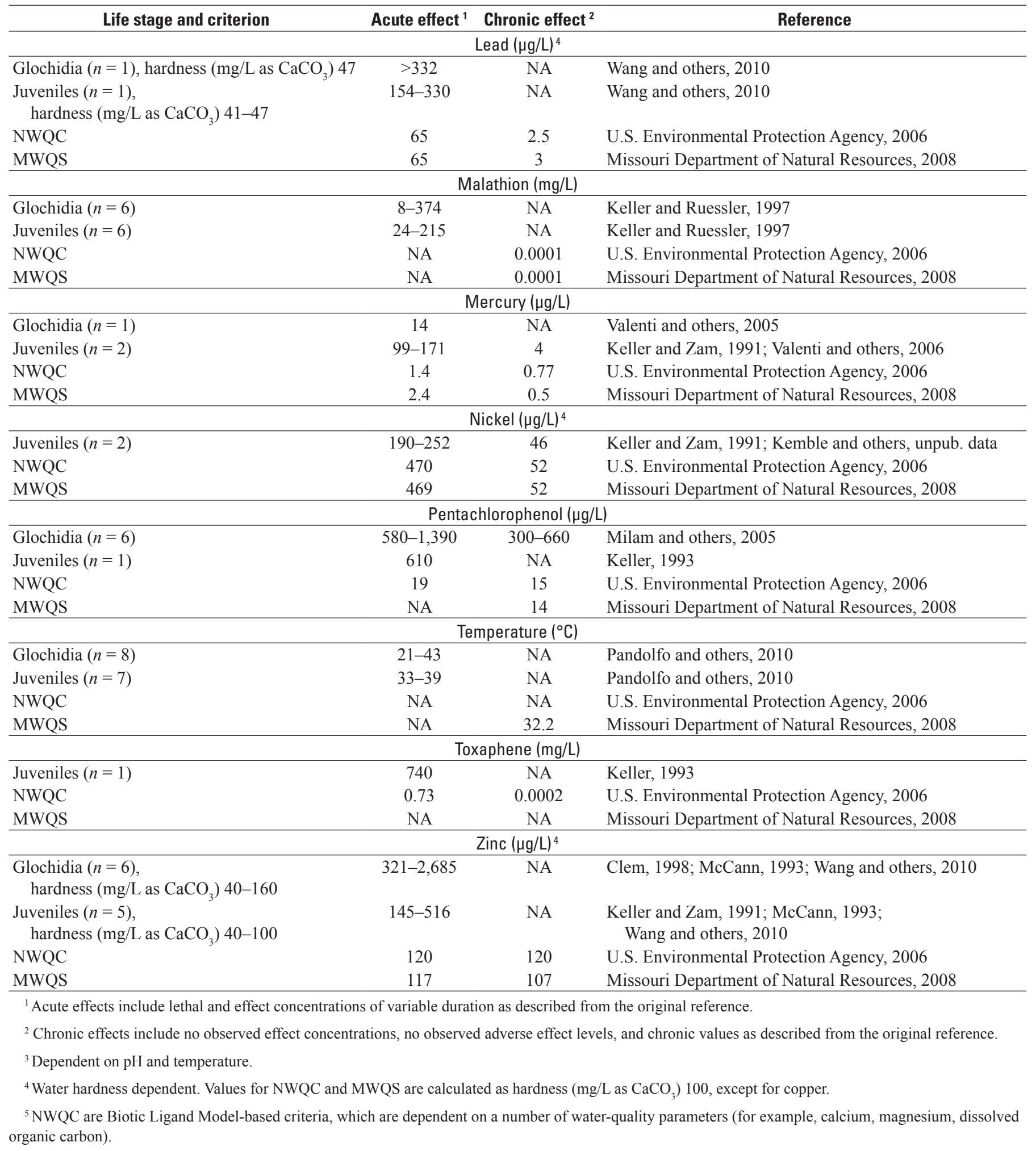




\section{Monitor Zebra Mussels in the Meramec River Basin}

Zebra mussel monitoring is warranted because they are pervasive in much of the United States and have been found in the lower basin and elsewhere in Missouri. Zebra mussels in the Meramec River would surpass habitat and water-quality parameters as the main threat to native mussels if they become established throughout the basin. Zebra mussels can destroy native mussel populations by competing for habitat and food sources, and they are difficult or impossible to eradicate once introduced. Potential infestations may increase if boat and personal watercraft traffic increases in the basin. Monitoring could focus on the lower basin or areas with greater boat traffic.

\section{Conduct Landscape Scale Modeling to Predict Mussel Distributions}

Landscape scale modeling may be the most useful tool to predict mussel distributions. Landscape scale analysis has already been conducted in the Meramec River Basin (Bayless and others, 2003; Sowa and others, 2007), and some biodiversity data, although not mussel specific, are available. Applying similar models to mussel distributions is in agreement with the goals of the Missouri Mussel Conservation and Management Plan (MDC, 2008) and could help identify data gaps. Other landscape scale models could be adapted to identify the stressors that limit a species distribution to certain river reaches (for example, Kapo and Burton, 2006). For example, physical (for example, sedimentation, substrate composition, turbidity) or chemical factors (for example, dissolved oxygen, ammonia, copper) potentially limiting species distributions of the Anodontinae and Lampsilinae in the Meramec River upstream from the Bourbeuse River confluence could be modeled. Future threats also could be incorporated into these models including mine development in the New Lead Belt, storm water runoff, biosolids applications, and personal care products and pharmaceuticals in wastewater treatment plant effluents.

\section{Protect Water Quality in Greater Biodiversity Areas as a Matter of Public Policy}

If all the toxicological information is generated and summarized to derive what could be protective environmental concentrations for mussels (for example, March and others, 2007), managers still may not be certain of the effect of large wastewater treatment plants or substantial sources of nonpoint source pollutants near important mussel beds. Even if mussel toxicity data are considered in permitted discharge limits, there may be some areas where the size of the discharge and the limits of available dilution would still be problematic because of the frequency and consequences of episodic events. Periodic exceedences of permitted discharge limits typically are anticipated and allowed. Whereas engineering failures are rare and may not pose a substantial risk to short-lived, mobile, and common species that re-colonize an area after an accident (for example, fish), these incidences would be a concern for rare, long-lived, relatively sedentary species like mussels. In areas of greater mussel diversity and excellent water quality, protecting the existing conditions may be an attractive option under antidegradation policies or designated uses. For example, the Oklahoma Department of Wildlife Conservation has designated mussel refugia in an attempt to provide mussel species a degree of protection and to facilitate their reproduction (March and others, 2007). North Carolina has a program allowing for site-specific water-quality standards for streams with federally-listed species, and that approach has been applied to a stream supporting the endangered Carolina heelsplitter (Lasmigona decorata) (Black, 2001; North Carolina Department of Environment and Natural Resources, 2007). These approaches may represent attractive options for situations like endangered mussel management (where risk aversion is an important consideration even when the risk is well-characterized) and for dealing with the current uncertainty in deriving protective limits for mussels.

\section{Implement Monitoring Studies to Assess Effects of Wastewater Treatment Plants and Areas of Suspected Nonpoint Source Pollution on Mussel Beds}

The Meramec River Basin has more than 100 wastewater treatment plants, and the lower 100 kilometers $(\mathrm{km})$ of Meramec River alone receives effluent from 6 facilities (Annis and others, 2009). Large concentrations of dead shell material have been observed in the channel downstream from several wastewater discharges in the Meramec River indicating the past presence of mussel beds (Andy Roberts, oral commun., 2009). Although the cause of the dead mussel beds was not determined, wastewater facilities are sources of ammonia, chlorine, personal care products and pharmaceuticals, and increased temperatures, all of which could have deleterious effects on mussel populations. Monitoring upstream and downstream from a facility would help determine differences in richness and abundance in native mussel beds; mussel sampling would be augmented with water-quality data collection. In situ exposures with propagated juveniles or laboratory testing of effluents would help delineate the effects on survival, growth, and reproduction. In addition, non-point source pollution from cattle grazing near and in streams, mining activities (gravel, lead), and urban runoff also are important to consider in monitoring studies (for example, Gangloff and others, 2009). 
Determine Sublethal Effects of Chemical Contaminants of Concern (for example, Ammonia, Metals, Common Use Pesticides, Synthetic Hormones, Medications, Personal Care Products) to Mussels

The toxicity of many common and emerging contaminants to mussels is unknown, and much of the data that are available have focused on lethal effects on early life stages of mussels. Moreover, many of these compounds are not regulated, and therefore do not have any associated MWQS or NWQC. More research on sublethal effects of contaminant exposure (that is, biomarkers associated with biotransformation enzymes, oxidative stress, reproductive effects, and immunology) and testing of older life stages of mussels may help determine if contaminants are affecting mussel recruitment as well as other biological processes. In addition to laboratory exposures, in situ exposures combined with analytical chemistry measurements using propagated juveniles ready for release into the Meramec River Basin could be used to examine the effects of multiple stressors (Cope and others, 2008) at specific sites of interest.

\section{Derive Risk-based Guidance Values for Mussel Protection}

When there is a need to estimate a protective concentration for a compound with little or no mussel toxicity data, data generation needs to be considered as has been done recently for several compounds (Bringolf and others, 2007a, b, c; Wang and others, 2007a, b, 2010). Protective concentrations for mussels can be estimated through aquatic risk assessment tools such as species sensitivity distributions (Suter and others, 2002) and interspecies correlation modes (Dyer and others, 2006). Both of these modeling approaches can make use of small datasets to provide estimates of protective concentrations. Examining the magnitude to which mussels are more sensitive to ammonia, glyphosate, copper, and other chemical contaminants than commonly tested fish and other invertebrates to derive adjustment factors for mussels also is warranted.

\section{Summary}

The Meramec River Basin supports high quality aquatic habitats with diverse mussel populations. However, surveys within the basin indicate that mussel distributions and diversity have declined throughout the past several decades. The main threats for mussels in the basin include excess sedimentation, altered stream geomorphology and flow, effects on riparian vegetation and condition, impoundments, invasive non-native species, and water-quality degradation. Although these threats were identified for the basin, these factors also could be considered in other basins where mussel conservation is a priority. Basin-specific information including mussel and fish host distribution surveys, water-quality data, land use data, and invasive species distributions would be needed to refine these potential threats. Determining habitat parameter and water-quality thresholds that protect native mussel populations is an essential, but complex task. Important habitat parameters to consider include excessive sedimentation, altered stream geomorphology and flow, altered riparian vegetation and condition, impoundments, and invasive species. In terms of water quality, mussels are more sensitive to certain changes in water quality and contaminants than other aquatic organisms; therefore, existing national water quality criteria and Missouri water quality standards may not be protective of mussels. Specifically, ammonia, copper, chlorine, temperature, glyphosatecontaining pesticides, personal care products, and pharmaceuticals pose the most severe risk to mussels based on the current scientific literature. Few of the organic compounds to which mussels are exposed in the environment have been evaluated in laboratory toxicity tests. In addition, many toxicological endpoints associated with older life stages of mussels have not been addressed (for example, mussel reproduction), and chronic exposures have been short-term relative to mussel life history (for example, only waterborne exposures conducted for as many as 28 days). Increasing water temperatures associated with global climate change or industrial discharges also could affect mussel populations. Research and management needs to conserve mussel diversity in the Meramec River Basin remain. Priority needs include establishing a long term mussel monitoring program that measures physical and chemical parameters of high priority, conducting landscape scale modeling to predict mussel distributions, determining sublethal effects of primary contaminants of concern, deriving risk-based guidance values for mussel conservation, and assessing the effects of wastewater treatment plants and nonpoint source pollution on mussels inhabiting the basin. A critical next step to further prioritize these needs is to conduct a watershed risk assessment using local data (for example, land use, flow) when available.

\section{References Cited}

Abell, R.A., Olson, D.M., Dinerstein, E., Hurley, P.T., Diggs, J.T., Eichbaum, W., Walters, S., Wettengel, W., Allnutt. T., Louks, C.J., and Hedao, P., 2000, Freshwater Ecoregions of North America. A Conservation Assessment: Island Press (WWF), Washington, D.C., 368 p.

Aldridge, D., Payne, B.S., and Miller, A.C., 1987, The effects of intermittent exposure to suspended solids and turbulence on three species of freshwater mussels: Environmental Pollution, v. 45, p. 17-28. 
American Society for Testing and Materials, 2010, Standard guide for conducting laboratory toxicity tests with freshwater mussels: E2455-06 in Annual Book of ASTM Standards, V. 11.06. West Conshocken, Pa., p. 1,365-1,416.

Annis, G.M., Diamond, D.D., and Garringer, A.J., 2009, Stream-reach specific watershed data: threats to aquatic ecosystem integrity: Final Report and Data for Missouri Department of Natural Resources, Jefferson City, Mo., 55 p.

Augspurger T., Dwyer, F.J., Ingersoll, C.G., and Kane, C.M., 2007, Editorial: Advances and opportunities in assessing the contaminant sensitivity of freshwater mussel early life stages: Environmental Toxicology and Chemistry, v. 26, p. 2,025-2,028.

Barnhart, M.C., Haag, W.R., and Roston, W.N., 2008, Adaptations to host infection and larval parasitism in Unionoida: Journal of the North American Benthological Society, v. 27, p. 370-394.

Bayless, M.A., McManus, M.G., and Fairchild, J.F., 2003, Geomorphic, water quality, and fish community patterns associated with the distributions of Notropis topeka in a Central Missouri watershed: The American Midland Naturalist, v. 150 , p. 58-72.

Beussink, Z.S., 2007, The effects of suspended sediment on the attachment and metamorphosis success of freshwater mussel parasitic life stages: Master's Thesis, Missouri State University, Springfield, Mo., 55 p.

Bidwell, R.J., Cooper, N., and Bruenderman, S.A., 2003, The influence of Asian clam (Corbicula fluminea) die-offs on sediment quality: Implications for native unionid mussels: Report to the U.S. Fish and Wildlife Service, Columbia, Mo. 25 p.

Black, M.C., 2001, Water quality standards for North Carolina's endangered mussels. Final Report: Department of Health Science, University of Georgia, Athens, Ga.

Blanc, T.J., Caldwell, M., and Hawks, M., 1998, Meramec River Watershed: Missouri Department of Conservation Report, Sullivan, Mo. Also available at http://extra.mdc. mo.gov/fish/watershed/meramec/contents/.

Brim Box, J., and Mossa, J., 1999, Sediment, land use, and freshwater mussels: Prospects and problems: Journal of the North American Benthological Society, v. 18, p. 99-117.

Bringolf, R.B., Cope, W.G., Eads, C.B., Lazaro, P.R., Barnhart, M.C., and Shea, D., 2007a, Acute and chronic toxicity of technical-grade pesticides to glochidia and juveniles of freshwater mussels (Unionidae): Environmental Toxicology and Chemistry, v. 26, p. 2,086-2,093.
Bringolf, R.B., Cope, W.G., Mosher, S., Barnhart, M.C., and Shea, D., 2007b, Acute and chronic toxicity of glyphosate compounds to glochidia and juveniles of Lampsilis siliquoidea Unionidae): Environmental Toxicology and Chemistry, v. 26 , p. 2,094-2,100.

Bringolf, R.B., Cope, W.G., Barnhart, M.C., Mosher, S., Lazaro, P.R., and Shea, D., 2007c, Acute and chronic toxicity of pesticide formulations (Atrazine, chlorpyrifos, and permethrin) to glochidia and juveniles of Lampsilis siliquoidea: Environmental Toxicology and Chemistry, v. 26, p. 2,101-2,107.

Brown, A.V., Lyttle, M.M., and Brown, K.B., 1998, Impacts of gravel mining on gravel bed streams: Transactions of the American Fisheries Society, v. 127, p. 979-994.

Buchanan, A.C., 1980, Mussels (Naiades) of the Meramec River Basin, Missouri: Missouri Department of Conservation Aquatic Series, no. 17, 76 p.

Buchanan, A.C., 1987, Die-off impacts on the mussel fauna of selected reaches of the Bourbeuse and Meramec Rivers, Missouri: in Neves, R.J., eds., Proceedings of the workshop on die-offs of freshwater mussels in the United States: June 1986 Upper Mississippi River Conservation Committee, Davenport, Iowa, p. 44-54.

Cherry, D.S, Van Hassel, J.H., Farris, J.L., Soucek, D.J., and Neves, R.J., 2002, Site-specific derivation of the acute copper criteria for the Clinch River, Virginia: Human and Ecological Risk Assessment, v. 8, p. 591-601.

Clem, S.A., 1998, Complexities in early life stage testing of freshwater mussels to selected metals: Master's Thesis, Arkansas State University, Jonesboro, Ark.

Conners, D.E, and Black, M.C., 2004, Evaluation of lethality and genotoxicity in the freshwater mussel Utterbackia imbecillis (Bivalvia: Unionidae) exposed singly and in combination to chemicals used in lawn care: Archives of Environmental Contamination and Toxicology, v. 6, p. 362-371.

Cope, W.G., Bringolf, R.B., Buchwalter, D.B., Newton, T.J., Ingersoll, C.G., Wang, N., Augspurger, T., Dwyer, F.J., Barnhart, M.C., Neves, R.J., and Hammer, E., 2008, Differential exposure, duration, and sensitivity of unionoidean bivalve life stages to environmental contaminants: Journal of the North American Benthological Society, v. 27, p. 451-462.

Czarnezki, J.M., 1987, Use of the plain pocketbook mussel, Lampsilis ventricosa, for monitoring heavy metal pollution in an Ozark stream: Bulletin of Environmental Contamination and Toxicology, v. 38, p. 641-646. 
Dwyer, F.J., Mayer, F.L., Sappington, L.C., Buckler, D.R., Bridges, C.M., Greer, I.E., Hardesty, D.K., Henke, C.E., Ingersoll, C.G., Kunz, J.L., Whites, D.W., Augspurger, T., Mount, D.R., Hattala, K., and Neuderfer, G.N., 2005, Assessing contaminant sensitivity of endangered and threatened aquatic species: Part 1. Acute toxicity of five chemicals: Archives of Environmental Contamination and Toxicology, v. 48, p. 143-154.

Dyer, S.D., Versteeg, D.J., Belanger, S.E., Chaney, J.G., and Mayer, F.L., 2006, Interspecies correlation estimates predict protective environmental concentrations: Environmental Science and Technology, v. 40, p. 3,102-3,111.

Ellis, M.M., 1936, Erosion silt as a factor in aquatic environments: Ecology, v. 17, p. 29-42.

Erickson, R.J., Benoit, D.A., Mattson, V.R., Nelson, H.P., and Leonard, E.N., 1996, The effects of water chemistry on the toxicity of copper to fathead minnows: Environmental Toxicology and Chemistry, v. 15, p. 181-193.

Fuller, S.L.H., 1974, Clams and mussels (Mollusca: Bivalvia): in Hart, C.W. Jr, and Fuller, S.LH., eds., Pollution ecology of freshwater invertebrates: Academic Press, N.Y. p. 215-273.

Gangloff, M.M., Siefferman, L., Seesock, W., and Webber, E.C., 2009, Influence of urban tributaries on freshwater mussel populations in a biologically diverse piedmont (USA) stream: Hydrobiologia, v. 636, p. 191-201.

Gangloff, M.M., and Feminella, J.W., 2007, Stream channel geomorphology influences mussel abundance in southern Appalachian streams, USA: Freshwater Biology, v. 52, p. 64-74.

Gillis, P.L., Mitchell, R.J., Schwalb, A.N., McNichols, K.A., Mackie, G.L., Wood, C.M., and Ackerman, J.D., 2008, Sensitivity of the glochidia (larvae) of freshwater mussels to copper: Assessing the effect od water hardness and siddoleved organic carbon on the sensitivity of endangered spcecies: Aquatic Toxicology, v. 88, p. 137-145.

Gooding, M.P., Newton, T.J., Bartsch, M.R., and Hornbuckle, K.C., 2006, Toxicity of synthetic musks to early life stages of the freshwater mussel Lampsilis cardium: Archive of Environmental Contamination and Toxicology, v. 51, p. 549-558.

Gore, J.A., Layzer, J.B., and Mead, J., 2001, Macroinvertebrate instream flow studies after 20 years: a role in stream management and restoration: Regulated Rivers: Research and Management, v. 17, p. 527-542.

Grabarkiewicz, J. and Davis, W., 2008, An introduction to freshwater mussels as biological indicators: EPA260-R-08-015, Office of Environmental Information, Washington, D.C., 122 p.
Hastie, L.C., Boon, P.J., Young, M.R., and Way, S., 2001, The effects of a major flood on an endangered freshwater mussel population: Biological Conservation, v. 98, p. 107-115.

Hastie, L.C., Cosgrove, P.J., Ellis, N., and Gaywood, M.J., 2003, The threat of climate change to freshwater pearl mussel populations: Ambio, v. 32, p. 40-46.

Henley, W.F., Patterson, M.A., Neves, R.J., and Lemly, A.D., 2000, Effects of sedimentation and turbidity on lotic food webs: a concise review for natural resource managers: Reviews in Fisheries Science, v. 8, p. 125-139.

Hubbs, D., McKinney, D., Sims, D., Lanier, S. and Black, P., 2006, Aggregate extraction impacts on Unionid mussel species richness and density: Proceedings of the Annual Conference of the Southeastern Association of Fish and Wildlife Agencies, v. 60, p. 169-173.

Jacobson, P.J., 1990, Sensitivity of early lifestages of freshwater mussels (Bivalvia: Unionidae) to copper. Master's Thesis, Virginia Poltechnic Institute and State University, Blacksburg, Va.

Jacobson, P.J., Farris, J.L., Cherry, D.S., and Nevees, R.J., 1993, Juvneile freshwater mussel (Bivalvia: Unionidae) responses to acute toxicity testing with copper: Environmental Toxicology and Chemistry, v. 12, p. 879-883.

Jacobson, P.J., Neves, R.J., Cherry, D.S., and Farris, J.L., 1997, Sensitivity of glochidial stages of freshwater mussels (bivalvia: Uniondea) to copper: Environmental Toxicology and Chemistry, v. 11, p. 2,384-2,392.

Kapo, K.E., and Burton, G.A., 2006, A geographic information systems-based, weights-of-evidence approach for diagnosing aquatic ecosystem impairment: Environmental Toxicology and Chemistry, v. 25, p. 2,237-2,249.

Keller, A.E., 1993, Acute toxicity of several pesticides, organic compounds, and a wastewater effluent to the freshwater mussel, Anodonta imbecilis, Ceriodaphnia dubia, and Pimephales promelas: Bulletin of Environmental Contamination and Toxicology, v. 51, p. 696-702.

Keller, A.E., and Zam, S.G., 1991, The acute toxicity of selected metals to the freshwater mussel, Anodonta imbecilis: Environmental Toxicology and Chemistry, v. 10, p. 539-546.

Keller, A.E., and Ruessler, D.S., 1997, The toxicity of malathion to unionid mussels: relationship to expected environmental concentrations: Environmental Toxicology and Chemistry, v. 16, p. 1,028-1,033. 
Klaine, S.J., Warren, L.W., and Summers, J.M., 1997, The use of juvenile mussels (Utterbackia imbecillis, Say) as a standardized toxicity testing organism. Final Report TIWET 09535: The Institute of Wildlife and Environmental Toxicology (TIWET), Clemson University, Pendleton, S.C.

Lasee, B.A., 1991, Histological and ultrastructural studies of larval and juvenile Lampsilis (Bivalvia) from the upper Mississippi River: PhD Dissertation, Iowa State University, Ames, Iowa.

Layzer, J.B., and Madison, L.M., 1995, Microhabitat use by freshwater mussels and recommendations for determining their instream flow needs: Regulated Rivers: Research and Management, v. 10, p. 329-345.

Lydeard, C., Cowie, R.H., Ponder, W.F., Bogan, A.E., Bouchet, P., Clark, S.A., Cummings, K.S., Frest, T.J., Gargominy, O., Herber, D.G., Hershler, R., Perez, K.E., Roth, B., Seddon, M., Strong, E.E., and Thompson, F.G., 2004, The global decline of nonmarine mollusks: Bioscience, v. 54 , p. 321-330.

Mackie, G.L., 1991, Biology of the exotic zebra mussel, Dreissena polymorpha, in relation to native bivalves and its potential impact in Lake St. Clair: Hydrobiologia, v. 219, p. 251-268.

March, F.A., Dwyer, F.J., Augspurger, T., Ingersoll, C.G., Wang, N., and Mebane, C.A., 2007, An evaluation of freshwater mussel toxicity data in the derivation of water quality guidance and standards for copper: Environmental Toxicology and Chemistry, v. 26, p. 2,066-2,074.

McCann, M.T., 1993, Toxicity of zinc, copper, and sediments to early life stages of freshwater mussels in the Powell River, Virginia: MSc Thesis, Virginia Polytechnic Institute and State University. Blacksburg, Va.

Milam, C.D., Farris, J.L., Dwyer, F.J., and Hardesty, D.K., 2005, Acute toxicity of six freshwater mussel species (glochidia) to six chemicals: Implications for daphnids and Utterbackia imbecillis as surrogates for protection of freshwater mussels (Unionidae): Archives of Environmental Contamination and Toxicology, v. 48, p. 166-173.

Missouri Department of Conservation, 2008, Missouri Mussel Conservation and Management Plan. Resource Science Division, Columbia, Mo., 52 p.

Missouri Department of Natural Resources, 2008, Missouri Water Quality Criteria. Available at http://www.dnr.mo.gov/ env/wpp/wqstandards/wq_criteria.htm. Accessed on September 24, 2010.

Missouri Resource Assessment Partnership, 2009, Stream reach specific watershed data: threats to aquatic ecosystems integrity: Final Report to the Missouri Department of Natural Resources, $83 \mathrm{p}$.
Morris, T.J., and Corkum, L.D., 1999, Unionid growth patterns in rivers of differing riparian vegetation: Freshwater Biology, v. 42, p. 59-68.

Neves, R. J., 1987, Recent die-offs of freshwater mussels in the United States: An overview: Neves, R. J., ed., Proceedings of the Workshop on Die-offs of Freshwater Mussels in the United States: Blacksburg, Va.: Virginia Tech Press, p. $7-18$.

Newton, T.J., Allran, J.W., O’Donnell, J.A., Bartsch, M.R., and Richardson, W.B., 2003, Effects of ammonia on juvenile unionid mussels (Lampsilis cardium) in laboratory sediment toxicity tests: Environmental Toxicology and Chemistry, v. 22, p. 2,554-2,560.

Newton, T.J., Woolnough, D.A., and Strayer, D.L., 2008, Using landscape ecology to understand and manage freshwater mussel populations: Journal of the North American Benthological Society, v. 27, p. 424-439.

North Carolina Department of Environment and Natural Resources, 2007, 'Redbook' Classifications and Water Quality Standards Applicable to Surface Waters and Wetlands of North Carolina (15A NCAC 2B .0100 and .0200): Department of Environment and Natural Resources, Division of Water Quality, Raleigh, N.C., 145 p.

Pandolfo, T.J., Cope, W.G., and Arellano, C., 2010, Temperature tolerance of juvenile freshwater mussels (Unionidae) under the added stress of copper: Environmental Toxicology and Chemistry, v. 29, p. 691-699.

Resh, V.H., and Rosenberg, D.M., 2010, Recent trends in lifehistory research on benthic macroinvertebrates: Journal of the North American Benthological Society, v. 29, p. 207-219.

Ricciardi, A., 2003, Predicting the impacts of an introduced species from its invasion history: an empirical approach applied to zebra mussel invasion: Freshwater Biology, v. 48, p. $972-981$.

Richter, B.D., Braun, D.P., Mendelson, M.A., and Master, L.L., 2000, Threats to imperiled freshwater fauna: Conservation Biology, v. 11, p. 1,081-1,093.

Roberts, A.D., and Barnhart, M.C., 1999, Effects of temperature, $\mathrm{pH}$, and $\mathrm{CO}_{2}$, on transformation of the glochidia of Anodonta suborbiculata on fish hosts and in vitro: Journal of North American Benthological Society, v. 18, p. 477-487.

Roberts, A.D., and Bruenderman, S., 2000, A reassessment of the status of freshwater mussels in the Meramec River Basin, Missouri: Missouri Department of Conservation, $141 \mathrm{p}$. 
Roberts, A.D., Mosby, D., Weber, J., Besser, J., Hundley, J., McMurray, S., and Faiman, S., 2009, An assessment of freshwater mussel (Bivalvia: Margaritiferidae and Unionidae) populations and heavy metal sediment contamination in the Big River, Missouri. US Fish and Wildlife Service Report, 114 p.

Rogers, C.L., and Dimock, R.V., 2003, Acquired resistance of bluegill sunfish Lepomis macrochirus to glochidia of the freshwater mussel Utterbackia imbecillus (Bivalvia: Unionidae) after multiple infections: Journal of Parasitology, v. 89, p. 582-594.

Santore, R.C., Paquin, P.R., DiToro, D.M, Allen, H.E, and Meyer, J.S., 2001, Biotic ligand model of the acute toxicity of metals. 2. Application to acutre copper toxicity in freshwater fish and Daphnia: Environmental Toxicology and Chemistry, v. 20, p. 2,397-2,402.

Schmitt, C.J., Finger, S.E., May, T.W., and Kaiser, M.S., 1987, Bioavailability of lead and cadmium from mine tailings to the pocketbook mussel (Lampsilis ventricosa): in Neves, R.J., eds., Proceedings of the workshop on die-offs of freshwater mussels in the United States: June 1986 Upper Mississippi River Conservation Committee, Davenport, Iowa, p. 115-142.

Sowa, S.P., Annis, G., Morey, M.E., and Diamond, D.D., 2007, A GAP analysis and comprehensive conservation strategy for riverine ecosystems of Missouri: Ecological Monographs, v. 77, p. 301-334.

Strayer, D.L., 1983, The effects of surface geology and stream size on freshwater mussel (Bivalvia, Unionidae) distribution in southeastern Michigan, U.S.A.: Freshwater Biology, v. 13, p. $253-264$.

Strayer, D.L, and Ralley, J., 1993, Microhabitat use by an assemblage of stream-swelling unionaceans (Bivalvia), including two rare species of Alasmidonta: Journal of the North American Benthological Society, v. 12, p. 247-258.

Strayer, D.L., 1999, Use of flow refuges by Unionid mussels in rivers. Journal of the North American Benthological Society, v. 18, p. 468-476.

Strayer, D.L., 2008, Freshwater Mussel Ecology: A multifactor approach to distribution and abundance: University of California Press, Los Angeles, Calif., 204 p.

Suter, G.W. II, Traas, T.P., and Posthuma, L., 2002, Issues and practices in the derivation and use of species sensitivity distributions: in Posthuma, L., Suter, G.W. II, and Traas, T.P., eds., Species sensitivity distributions in ecotoxicology: Lewis Publishers, Boca Raton, Fla., p. 437-474.
Turgeon, D.D., Bogan, A.E., Coan, E.V., Emerson, W.K., Lyons, W.G., Pratt, W.L., Roper, D.F., Scheltema, A., Thompson, F.G., and Williams, J.D., 1988, Common and scientific names of aquatic invertebrates from the United States and Canada: mollusks: American Fisheries Society, Special Publication 16, 277 p.

U.S. Environmental Protection Agency, 1985, Guidelines for deriving numerical national water quality criteria for the protection of aquatic organisms and their uses:U.S. Environmental Protection Agency, Office of Research and Development, Washington, D.C., 104 p.

U.S. Environmental Protection Agency, 1999, 1999 Update of ambient water quality criteria for ammonia: EPA 822/ R99/014. Technical Report. Office of Water, Washington, D.C., 153 p.

U.S. Environmental Protection Agency, 2006, National Recommended Water Quality Criteria: available at http://www. epa.gov/waterscience/criteria/wqctable/\#K (accessed on September 24, 2010), Office of Water, Washington, D.C.

U.S. Environmental Protection Agency, 2007, Aquatic life ambient freshwater quality criteria - copper, 2007 revision: EPA-822-R-07-001, Office of Water, Washington, D.C., 204 p.

U.S. Environmental Protection Agency, 2009, Draft 2009 update of aquatic life ambient water quality criteria for ammonia - freshwater: EPA-882-D-09-001, Office of Water, Washington, D.C., 192 p.

Valenti, T.W., Cherry, D.S., Neves, R.J., and Schmerfeld, J., 2005, Acute and chronic toxicity of mercury to early life stages of the rainbow mussel, Villosa iris (Bivalvia: Unionidae): Environmental Toxicology and Chemistry, v. 24, p. 1,242-1,246.

Valenti, T.W., Cherry,D.S., Currie, R.J., Neves, R.J., Jones, J.W., Mair, R., and Kane, C.M., 2006, Chlorine toxicity of early life stages of freshwater mussels (Bivalvia: Unionidae): Environmental Toxicology and Chemistry, v. 25, p. 2,512-2,518.

Vaughn, C.C., Nichols, S.J., and Spooner, D.E., 2008, Community and foodweb ecology of freshwater mussels: Journal of the North American Benthological Society, v. 27, p. 409-423.

Wang, N., Ingersoll, C.G., Hardesty, D.K., Ivey, C.D., Kunz, J.L., May, T.W., Dwyer, F.J., Roberts, A.D., Augspurger, T., Kane, C.M., Neves, R.J., and Barnhart, M.C., 2007a, Acute toxicity of copper, ammonia, and chlorine to glochidia and juveniles of freshwater mussels (Unionidae): Environmental Toxicology and Chemistry, v. 26, p. 2,036-2,047. 
Wang, N., Ingersoll, C.G., Greer, I.E., Hardesty, D.K., Ivey, C.D., Kunz, J.L., Brumbaugh, W.G., Dwyer, F.J., Roberts, A.D., Augspurger, T., Kane, C.M., Neves, R.J., and Barnhart M.C., 2007b, Chronic toxicity of copper and ammonia to juvenile freshwater mussels (Unionidae): Environmental Toxicology and Chemistry, v. 26, p. 2,048-2,056.

Wang, N., Erickson, R.J., Ingersoll, C.G., Ivey, C.D., Brunson, E.L., Augspurger, T., and Barnhart, M.C., 2008, Influence of $\mathrm{pH}$ on the acute toxicity of ammonia to juvenile freshwater mussels (fatmucket, Lampsilis siliquoidea): Environmental Toxicology and Chemistry, v. 27, p. 1,141-1,146.

Wang, N., Mebane, C.A., Kunz, J.L., Ingersoll, C.G., May, T.W., Arnold, W.R., Santore, R.C., Augspurger. T., Dwyer, F.J., and Barnhart, M.C., 2009, Evaluation of acute copper toxicity to juvenile freshwater mussels (fatmucket, Lampsilis siliquoidea) in natural and reconstituted waters: Environmental Toxicology and Chemistry, v. 28, p. 2,367-2,377.

Wang, N., Ingersoll, C.G., Ivey, C.D., Hardesty, D.K., May, T.W., Roberts, A.D., Augspurger, T., van Genderen, E., and Barnhardt, M.C., 2010, Sensitivity of early life stages of freshwater mussels (Unionidae) to acute and chronic toxicity of lead, cadmium, and zinc in water: Environmental Toxicology and Chemistry, v. 29, p. 2,053-2,063.

Warren, L.W., 1996, The use of juvenile mussels, Utterbackia imbecillis Say (Bivalvia: Unionidae), as a standardized toxicity testing organism: Master's Thesis, Clemson University, Clemson, S.C.
Watters, G.T., 1996, Small dams as barriers to freshwater mussels (Bivalvia, Unionida) and their hosts: Biological Conservation, v. 75, p. 79-85.

Watters, G.T., 1999, Freshwater mussels and water quality: a review of effects of hydrologic and instream habitat alterations: Proceedings of the First Freshwater Mollusk Conservation Society Symposium, p. 261-274.

Watters, T.G. and O’Dee, S.H., 1998, Metamorphosis of freshwater mussel glochidia (Bivalvia: Unionidae) on amphibians and exotic fishes: The American Midland Naturalist, v. 139, p. 49-57.

Williams, J.D., Warren, M.L., Cummings, K.S., Harris, J.L., and Neves, R.J., 1993, Conservation status of freshwater mussels of the United States and Canada: Fisheries, v. 18, p. 6-22.

Yeager, M.M., Neves, R.J., and Cherry, D.S., 2000, Competitive interactions between early life stages of Villosa iris (Bivalvia: Unionidae) and adult Asian clams (Corbicula fluminea): Proceedings of the First Freshwater Mollusk Conservation Society Symposium, p. 253-259.
Prepared by:

Rolla Publishing Service Center

For more information concerning this publication, contact: Director, U.S. Geological Survey

Columbia Environmental Research Center

4200 New Haven Road, Columbia, M0 65201

(573) 875-5399

Or visit the Columbia Environmental Research Center website at: http://www.cerc.usgs.gov 

